\title{
ANALISIS PERKEMBANGAN KREDIT MACET PADA PT. BANK MANDIRI (PERSERO) TbK. UNIT KCP MMU ARGAMAKMUR
}

\author{
Ameliana \\ Repuadi \\ Program Studi Akuntansi \\ Fakultas Ekonomi Universitas Dehasen Bengkulu
}

\begin{abstract}
ABSTRAK
Ameliana, Repuadi: Analisis Perkembangan Kredit Macet pada PT. Bank Mandiri (PERSERO) TBK. Unit KCP MMU Argamakmur. Penelitian ini adalah kuantitatif. Formula dari masalah penelitian ini adalah bagaimana perkembangan dari non-performing loans di PT Bank Mandiri (Persero) Tbk. KCP unit MMU Argamakmur. Metode pengumpulan data menggunakan dokumentasi dan observasi. Metode analisis yang digunakan adalah kuntitatif. Perkembangan kredit macet pada tahun 2012, mulai terjadi pada bulan Juni 2012 sebesar Rp 79.000.000 hingga nilai tertinggi kredit macet terjadi pada bulan November 2012 sebesar Rp 107.000.000, tetapi hal tersebut masih dapat dilakukan upaya pelunasan angsuran oleh nasabah sehingga pada bulan Desember 2012 tersisa kredit macet sebesar Rp 9.000.000. Pada tahun 2013 pada bulan Januari kembali naik menjadi Rp 111.000.000, tetapi upaya penagihan dan pendekatan pada nasabah tetap dilakukan sehingga bulan Mei 2013 turun menjadi sebesar Rp 19.000.000 walaupun pada bulan Agustus 2013 naik kembali menjadi Rp 52.000.000. Dari faktor kesehatan Bank nilai kredit macet masih dalam kriteria baik (sehat) karena nilai NPL masih berada antara $0 \%-5 \%$.
\end{abstract}

\begin{abstract}
Ameliana, Repuadi: An Analysis of Non-Performing Loans Development at Mandiri Bank in Argamakmur. This research used quantitative research. Formulation of the problem in this study is how the development of non-performing loans at PT. Bank Mandiri (Persero) Tbk. Unit MMU KCP Argamakmur. And the methods for collecting data are the documentation and observation. And analysis method used quantitative method. In 2012, the development of non-performing loans begun with an amount 79.000.0000 in June until reached the highest non-performing loans in November, 107.000.000. But this case still can be solved by the customers with installment repayment efforts, so in December 2012, the remaining of non-performing loans has shrinkaged in amount 9000.000. Unfortunately, in January 2013, it rose until 111 millions, but the collection efforts and approaches to the customers are still being done, a result of it, is the non-performing loans fell to 19 millions, although in August rose again to 52 millions. From this case indicated that the condition of Bank is still in good criteria because the NPL's value is around 0\% to 5\%.
\end{abstract}

\section{Kata kunci: Kredit macet}

\section{PENDAHULUAN}

Bisnis pada abad 21 akan semakin banyak menghadapi tantangan karena konsumen lebih memandang kepada produk yang lebih high-quality, low cost dan juga harus responsif terhadap perubahan yang sangat cepat. Pada banyak industri perubahan sosial politik yang cepat contohnya CAFTA akan meningkatkan jumlah dan kekuatan pesaing-pesaing baru dari negara asing. Kompleksitas dan tantangan yang dihadapi tersebut menuntut suatu usaha untuk memiliki strategi inovasi yang tepat sehingga mampu bersaing dengan competitor pada khususnya competitiordari negara lain.

Dari perspektif dunia, diakui bahwa kredit usaha mikro (KUM) memainkan suatu peran yang sangat vital di dalam pembangunan dan pertumbuhan ekonomi, tidak hanya di negaranegara sedang berkembang tetapi juga di negara-negara maju. KUM sangat penting karena 
karakteristik-karakteristik utama mereka yang berbeda dengan usaha besar, yakni: 1) Jumlah perusahaan sangat banyak (jauh melebihi jumlah usaha besar), 2) Karena sangat padat karya, berarti mempunyai suatu potensi pertumbuhan kesempatan kerja yang sangat besar, 3) mayoritas KUM berada dipedesaan, 4) KUM memakai teknologi yang lebih "cocok" terhadap proporsi-proporsi dari faktor-faktor produksi dan kondisi lokal seperti sumber daya alam dan tenaga kerja yang berpendidikan rendah, 5) Banyak KUM bisa bertahan pada krisis contohnya krisis besar yang melanda Indonesia padatahun 1997/98,6) banyak orang-orang desa yang miskin dan bisa menabung dan mereka mau menabung dan juga mengambil risiko dengan melakukan investasi dengan mendirikan usaha kecil, 7) secara umum produksi barang-barang KUM selain untuk masyarakat kelas menengah dan atas tetapi lebih banyak yang memproduksi untuk pasar masyarakat berpendapatan rendah, 8) sebagai bagian dari dinamika, banyak juga KUM yang mampu meningkatkan produktivitasnya lewat investasi dan perubahan teknologi, 9) dan yang terakhir keunggulan dari KUM adalah tingkat fleksibilitasnya yang tinggi, relatif terhadap pesaingnya (usaha besar).

Kredit usaha mikro (KUM) juga diyakini memiliki peran yang penting dan strategis, ditinjau dari beberapa aspek. Pertama, jumlah industrinya yang besar dan terdapat dalam setiap sektor ekonomi. Berdasarkan data Biro Pusat Statistik dan Kementerian Koperasi dan UKM tahun 2009, jumlah kredit usaha mikro (KUM) tercatat 52,723 juta unit atau 99,9\% dari total unit usaha. Kedua, potensinya yang besar dalam penyerapan tenaga kerja, setiap unit investasi pada sektor KUM dapat menciptakan lebih banyak kesempatan kerja bila dibandingkan investasi yang sama pada usaha besar. Pada tahun 2009 sektor KUM mampu menyerap 96,211 juta tenaga kerja atau 97,3 \% dari total angkatan kerja yang bekerja. Ketiga, kontribusi KUM dalam pembentukan PDB cukup signifikan yakni sebesar Rp 2.280 triliun dari total PDB Rp 5.294 triliun.

Dengan trend perkembangan jumlah unit KUM yang semakin meningkat tiap tahunnya kemudian penyerapan tenaga kerja pada sektor KUM ini juga semakin meningkat tiap tahunnya ditambah kontribusinya terhadap PDB yang meningkat setiap tahunnya juga merupakan hal yang menguntungkan bagi perekonomian Indonesia. Banyak kalangan perbankan mulai merambah ke bisnis mikro ini dengan menyalurkan kredit, selain itu sudah banyak upaya pemerintah yang dilakukan untuk pendanaan KUM lewat kredit. Menteri Negara Koperasi (Menegkop) dan UKM sejak berakhirnya era orde baru hingga saat ini juga menyalurkan kredit, tetapi dalam bentuk dana bergulir, yang selama periode 2000-2007, totalnya telah mencapai Rp 3,085 triliun.

Dana ini pada dasarnya adalah dana investasi, bukan dana sosial dimaksudkan untuk penguatan modal KUM yang disalurkan lewat Badan Layanan Umum atau Lembaga Pengelola Dana Bergulir (LPDB). Di bidang perbankan penyaluran kredit ini juga semakin menjadi pangsa pasar yang cukup menjanjikan, Selain bank-bank kecil dan BPR, kini hampir semua bank besar menceburkan diri ke bisnis micro banking. Kehadiran bank-bank besar yang melengkapi bank kecil dan BPR dibisnis ini memberikan keragaman pilihan bagi kalangan usaha kecil saat berhubungan dengan perbankan, pintu dan kucuran kredit pun makin banyak (InfoBank, 2011).

Persero, BPD, Bank Swasta Nasional dan Bank Asing memiliki tren peningkatan jumlah penyaluran kredit usaha mikro tiap tahunnya. Secara keseluruhan dari tahun 2008 penyaluran kredit yang diberikan keempat kelompok bank tersebut berjumlah Rp 633 triliun meningkat menjadi Rp 920 triliun pada tahun 2011. Perkembangan Kredit Usaha Mikro per kelompok Bank (dalam Milyar)

Perlu diwaspadai juga pembiayaan kredit kepada KUM yang akhir-akhir ini semakin kencang dikucurkan oleh lembaga keuangan maupun perbankan mempunyai resiko yang besar juga, hal ini karena masih belum optimalnya KUM pada pengelolaan kredit yang di gunakan. Pada kenyataannya selalu ada sebagian nasabah yang karena suatu sebab tidak dapat mengembalikan kredit kepada bank yang telah meminjaminya. Akibat nasabah tidak dapat membayar lunas utangnya, maka menjadikan perjalanan kredit terhenti atau macet. Perkreditan KUM tak terlepas dari permasalah kredit macet ini, Bisa dilihat dari data NPL (Non Performing Loan) kredit usaha mikro (KUM) yang mengalami kenaikkan tiap tahunnya pada masing-masing bank menurut kelompoknya. 
Penyebab timbulnya kredit bermasalah diantaranya ketidaklayakan debitur kemudian faktor ekstern yang terdiri dari penurunan kondisi ekonomi moneter negara atau sektor usaha, debitur yang mengalami bencana alam (kebakaran, banjir, gempa, dll) dan peraturan pemerintah dapat menjadi sebab lain merosotnya kemampuan debitur mengembalikan kredit. Behrens dalam Sutojo (2000:23), menyebutkan juga tiga sebab utama kredit bermasalah oleh yaitu, salah urus (mismanagement), kurangnya pengetahuan dan pengalaman pemilik dalam bidang usaha bisnis dimana mereka beroperasi, dan penipuan (fraud). Dari ketiga sebab tersebut menurut Behrens yang paling besar pengaruhnya adalah salah urus atau (mismanagement).

Salah satu perbankan yang menyalurkan KUM adalah Bank Mandiri yang memeliki cabang di setiap provinsi di Indonesia dan Kantor Cabang Pembantu di setiap Kabupaten, salah satunya adalah Unit KCP MMU Argamakmur. Dalam perkembangan penyaluran KUM pada PT. Bank Mandiri (Persero) Tbk. Unit KCP MMU Argamakmur tidak terlepas terjadinya macet. Kredir macet pada PT. Bank Mandiri dibagi dengan tiga kriteria, yaitu:

a. Kurang lancar, yaitu angsuran kredit sudah melewati 91-120 hari dari batas waktu yang telah disepakati.

b. Diragukan, yaitu angsuran kredit sudah mencapai 121-180 hari dari batas waktu yang telah disepakati.

c. Macet, yaitu angsuran kredit sudah mencapai 181 hari dari batas.

Hasil pengamatan menunjukkan bahwa kemacetan kredit tersebut disebabkan oleh nasabah yang diakibatkan dua hal yaitu, 1) adanya unsur kesengajaan artinya nasabah sengaja tidak mau membayar kewajibannya kepada bank sehingga kredit yang diberikan dengan sendiri macet, 2) unsur ketidaksengajaan, yaitu nasabah memiliki kemauan untuk membayar akan tetapi tidak mampu dikarenakan usaha yang dibiayai terkena musibah. Faktor yang mempengaruhi terjadinya kredit macet berasal dari nasabah diantaranya nasabah menyalah gunakan kredit yang diperolehnya, kemudian nasabah yang kurang mampu mengelolanya dan nasabah yang beritikad tidak baik.

\section{TINJAUAN LITERATUR Manajemen Kredit}

Kegiatan-kegiatan perkreditan adalah bagaimana mengatur, mengelola pemanfaatan dana supaya produktif dengan kata lain dapat disalurkan atau diinvestasikan dalam bentuk kredit dengan prosedur-prosedur yang dirancang sehingga dapat diyakini bahwa dana yang disalurkan tersebut dapat kembali sesuai dengan perjanjian yang telah disepakati bersama. Untuk mencapi hal tersebut diperlukan majemen yang dalam mengelola kredit tersebut.

Sebelum dijelaskan tentang manajemen kredit terlebih dahulu akan dijelaskan pengertian manajemen dan pengertian kredit. Manajemen merupakan merupakan suatu seni mengatur orang-orang untuk dapat menyelesaikan tanggung jawab yang dibebankan kepadanya sesuai dengan tujuan yang telah ditetapkan atau direncankan sebelumnya. Hal ini sejalan dengan pengertian manajemen yang dikemukan oleh Follett, mengandung arti bahwa manajer mencapai tujuan-tujuan organisasi melalui pengaturan orang-orang lain untuk melaksanakan berbagai pekerjaan itu sendiri (Handoko, 2008:3).

Terry dan Rue (2005:1), menjelaskan manajemen adalah : "Suatu proses atau kerangka kerja, yang melibatkan bimbingan atau pengarahan suatu kelompok orang-orang kearah tujuantujuan organisasi atau maksud-maksud yang nyata". Pengertian ini mengandung manajemen adalah suatu kegiatan, pelaksanaannya adalah managing atau pengelolaan, sedang pelaksanaannya disebut manager atau pengelola. Manajemen mempunyai tujuan tertentu dan tidak dapat diraba. Ia berusaha untuk mencari hasil-hasil tertentu, yang biasanya diungkapkan dengan istilah-istilah "objectivives" atau hal-hal yang nyata.

Selain sebagai suatu proses manajemen juga sering diartikan sebagai suatu seni seperti dikemukakan oleh Follett di atas yang mengandung makna bahwa untuk mencapai tujuan diperlukan bagaima cara mengatur orang-orang dalam organisasi dengan pendekatan seni. 
Seni adalah pengetahuan bagaimana mencapai hasil yang diinginkan. Ia adalah kecakapan yang diperoleh dari pengalaman, pengamatan dan pelajaran serta kemampuan untuk menggunakan pengetahuan manajemen. Seni manajemen menghendaki kreativitas, atas dasar dan dengan syarat suatu pengertian mengenai ilmu manajemen. Maka karena itu, ilmu pengetahuan dan seni manajemen merupakan komponennya masing-masing. Kalau yang satu meningkat, demikian pulalah harusnya, perlu ada keseimbangan antara keduanya (Terry dan Rue, 2005:2).

Dari pengertian di atas dapat disimpulkan bahwa manajemen adalah suatu ilmu dan seni mengatur, yaitu bagaimana membuat perencanaan, pengorganisasian, mengarahkan dan mengendalikan sumber daya yang ada baik sumber daya manusia maupun maupun sumber daya lain yang menunjang pencapaian tujuan dari sebuah organisasi.

Perkembangan suatu perusahaan tidak terlepas dari kredit, karena kredit sangat bermanfaat untuk menambah modal kerja dalam mempertahankan dan mengembangkan kelangsungan usaha. Pengertian kredit mempunyai dimensi yang beraneka ragam, dimulai dari kata "Kredit" yang berasal dari bahasa Italia credere yang artinya kepercayaan, yaitu kepercayaan dari kreditor bahwa debitornya akan mengembalikan pinjaman beserta bunganya sesuai dengan perjanjian kedua belah pihak. Tegasnya kreditor percaya bahwa kredit itu tidak akan macet (Hasibuan, 2008:87).

Prinsip penyaluran kredit adalah prinsip kepercayaan dan kehati-hatian. Indikator kepercayaan ini adalah kepercayaan moral, komersial, finansial dan agunan. Menurut Hasibuan (2008:87), membedakan dua jenis kepercayaan, antara lain:

a. Kepercayaan murni, adalah jika kreditor memberikan kredit kepada kreditornya atas dasar kepercayaan saja tanpa ada jaminan lainnya.

b. Kepercayaan reserve, diartikan kreditor menyalurkan kredit/pinjaman kepada debitor atas kepercayaan, tetapi kurang yakin sehingga bank selalu meminta agunan berupa materi (seperti BPKB, dan lain-lain).

Dalam praktek sehari-hari pengertian kredit berkembang lebih luas lagi, seperti yang dijelaskan oleh Kohler, kredit adalah "Kemampuan untuk melaksanakan suatu pembelian atau mengadakan suatu pinjaman dengan suatu janji pembayarannya akan dilakukan ditangguhkan pada suatu jangka waktu yang disepakati" (Muljono, 2001:9).

Menurut Undang-Undang Nomor 10 Tahun 1998 pasal 1 ayat 11 kredit adalah:

"Penyediaan uang atau tagihan yang dapat dipersamakan dengan itu, berdasarkan persetujuan yang dapat dipersamakan dengan itu berdasarkan persetujuan atau kesepakatan pinjam meminjam antara bank dan pihak lain yang diwajibkan pihak peminjam untuk melunasi hutangnya setelah jangka waktu tertentu dengan pemberian bunga, imbalan atau pembagian hasil keuntungan".

Dari pengertian kredit di atas ada beberapa kesimpulan yang dapat ditarik:

a. Adanya suatu penyerahan uang/tagihan atau dapat juga barang yang menimbulkan tagihan tersebut kepada pihak lain, dengan harapan memberi pinjaman ini bank akan memperoleh suatu tambahan nilai dari pokok pinjaman tersebut yang berupa bunga sebagai pendapatan bagi bank yang bersangkutan.

b. Dari proses kredit itu telah didasarkan pada suatu perjanjian yang saling mempercayai kedua belah pihak akan mematuhi kewajiban masing-masing.

c. Dalam pemberian kredit ini terkandung kesepakatan pelunasan utang dan bunga akan diselesaikan dalam jangka waktu tertentu yang telah disepakati bersama.

Dalam praktik sehari-hari persetujuan pinjaman kredit dinyatakan dalam bentuk perjanjian tertulis baik di bawah tangan maupun secara notariil, dan sebagai pengamanan bahwa pihak peminjam akan memenuhi kewajibannya menyerahkan suatu jaminan baik yang bersifat kebendaan maupun bukan kebendaan.

Dari pengertian kredit di atas perlu dipahami benar bahwa pengertian kredit tersebut lebih menekankan pada pengertian kredit yang disalurkan atau yang diberikan oleh bank atau lembaga keuangan lainnya kepada masyarakat bukan kredit yang berlaku dalam masyarakat luas seperti halnya pada abang kredit yang memberikan kredit alat-alat rumah tangga di desadesa dan juga bukan kredit dealer atau leasing ataupun kredit yang diberikan seorang rentenir. 
Agar kredit yang disalurkan baik atas kepercayaan murni maupun kepercayaan reserve dapat berjalan dengan baik maka diperlukan manajemen kredit profesional. Hasibuan (2008:87), mendefinisikan manajemen perkreditan bank adalah: "Kegiatan mengatur pemanfaatan dana-dana bank, supaya produktif, aman dan giro wajib minimalnya tetap sehat". Manajemen perkreditan akan dapat dilakukan dengan baik jika didasarkan perhitungan yang matang dan terpadu dari pendapatan, keamanan, dan giro wajib minimal. Oleh karena itu pimpinan bank dituntut agar melaksanakan perencanaan, alokasi, dan kebijasanaan penyaluran kreditnya.

Definisi lain tentang manajemen perkreditan bank dikemukakan oleh Sinunungan, adalah: "Pada dasarnya merupakan suatu proses yang terintegrasi antara sumber-sumber dana kredit, alokasi dana yang dapat dijadikan kredit dengan perencanaan, pengorganisasian, pemberian administrasi dan pengamanan kredit" (Hasibuan, 2008:88).

Dari pengertian manajemen kredit di atas dapat disimpulkan bahwa manajemen kredit adalah kegiatan bagaimana mengelola dana bank untuk disalurkan dalam bentuk kredit sehingga dana tersebut dapat dikembalikan oleh kreditor sesuai dengan kesepakatan yang telah disepakati.

\section{Jenis-Jenis Kredit}

Kredit yang diberikan bank umum dan bank perkreditan rakyat untuk masyarakat terdiri dari berbagai jenis. Menurut Taswan (2003:163) jenis kredit yang diberikan oleh bank sangat bervariasi, misalnya kredit investasi, konsumsi, kredit produktif, kredit perumahan (KPR), kredit sindikasi, kredit kendaraan dan sebagainya. Namun demikian, secara umum jenis pemberian kredit terdiri dari beberapa jenis, antara lain:

a. Jenis kredit menurut bentuknya:

1. Kredit Rekening Koran

Dalam hal ini debitur diberi hak untuk menarik dana rekening korannya sampai dengan sebesar plafond yang ditetapkan bank.

2. Instaallment Loan

Kredit ini adalah kredit yang angsuran pokok dan bunganya dilakukan secara teratur menurut jadwal waktu yang telah disepakati antara bank dengan debitur, dengan nilai konstan selama berlangsungnya masa kredit tersebut.

b. Jenis kredit menurut jangka waktu:

1. Kredit jangka pendek, adalah kredit yang berjangka waktu maksimum satu tahun, namun termasuk kredit tanaman musiman yang berjangka waktu lebih dari satu tahun.

2. Kredit jangka menengah, adalah kredit yang berjangka waktu antara satu sampai dengan tiga tahun, kecuali kredit untuk tanaman musiman.

3. Kredit jangka panjang, adalah kredit yang berjangka waktu lebih dari tiga tahun.

c. Jenis kredit menurut kegunaannya:

1. Kredit modal kerja, adalah kredit yang diberikan dengan tujuan untuk membiayai modal kerja usaha.

2. Kredit investasi, adalah kredit yang diberikan untuk membiayai investasi suatu usaha.

3. Kredit konsumsi, adalah kredit yang diberikan untuk keperluan konsumsi

Sedangkan menurut Widiani (2008:28) selain jenis kredit di atas juga terdapat jenis kredit berdasarkan kredit menurut kolektibiitasnya atau kualitasnya yaitu:

a. Lancar (L), apabila kemampuan membayar tepat waktu, perkembangan rekening baik dan tidak ada tunggakan serta sesuai dengan persyaratan kredit yang telah disepakati bersama.

b. Kredit dalam perhatian khusus (DPK), apabila terdapat tunggakan pembayaran pokok dan atau bunga sampai dengan 90 hari.

c. Kredit Kurang Lancar (KL), apabila terdapat tunggakan pokok dan bunga yang telah melampaui 90 hari sampai dengan 180 hari, serta terdapat cerukan yang berulangkali khususnya untuk menutupi kerugian operasional dan kekurangan kas. 
d. Kredit diragukan (D), apabila terdapat tunggakan dan/atau bunga yang telah melampaui 180 hari sampai dengan 270 hari, serta terjadi cerukan yang bersifat permanen khususnya untuk menutupi kerugian operasional dan kekurangan kas.

e. Kredit macet (M), apablia kredit dikatakan macet apabila terdapat tunggakan pokok dan bunga yang melampai 280 hari.

\section{Unsur-Unsur Kredit}

Menurut Kasmir (2008:98) unsur-unsur dalam kredit adalah:

a. Kepercayaan, yaitu suatu keyakinan pemberi kredit bahwa kredit yang di berikan (berupa uang atau jasa) akan benar-benar diterima kembali di masa di masa datang.

b. Kesepakatan, selain unsur percaya di dalam kredit juga mengandung unsur kesepakatan antara pemberi kredit dan penerima kredit. Kesepakatan ini di tuangkan dalam suatu perjanjian di mana masing-masing pihak menandatangani hak dan kewajibannya masingmasing.

c. Jangka waktu, jangka waktu ini mencakup masa pengembalian kredit yang telah disepakati. Jangka waktu tersebut bisa berbentuk jangka pendek, jangka menengah, atau jangka panjang.

d. Risiko, adanya suatu tenggang waktu pengembalian akan menyebabkan suatu resiko tidak tertagihnya/macet pemberian kredit. Semakin panjang suatu kredit semakin besar resikonya demikian pula sebaliknya. Risiko ini menjadi tanggungan bank, baik risiko yang disengaja oleh nasabah yang lalai, maupun oleh risiko yang tidak sengaja.

e. Balas Jasa, merupakan keuntungan atas pemberian suatu kredit atau jasa tersebut yang kita kenal dengan nama bunga. Balas jasa dalam bentuk bunga dan biaya administrasi kredit ini merupakan keuntungan bank.

Kredit diberikan atas dasar kepercayaan sehingga pemberian kredit berarti pemberian kepercayaan. Hal ini berarti bahwa prestasi yang diberikan benar-benar di yakini dapat dikembalikan oleh penerima kredit sesuai dengan waktu dan syarat-syarat yang telah disepakati bersama. Dengan demikian, apabila unsur-unsur tersebut diatas dianalisis oleh pihak dengan baik, diharapkan kredit yang diberikan kepada debitor dapat dikembalikan tepat pada waktunya sesuai dengan parjanjian dan dengan tingkat risiko yang sangat kecil.

Dalam melakukan penilaian kriteria-kriteria serta aspek penilaiannya tetap sama. Begitu pula dengan ukuran-ukuran yang ditetapkan sudah menjadi standar penilaian setiap bank. Biasanya kriteria penilaian yang harus dilakukan oleh bank untuk mendapatkan nasabah yang benar-benar menguntungkan dilakukan dengan analisis 5C dan 7P. Metode analisis 5C, antara lain sebagai berikut :

a. Character, adalah suatu keyakinan bahwa sifat atau watak dari orang-orang yang akan diberikan kredit benar-benar dapat dipercaya, hal ini tercermin dari latar belakang si nasabah baik dari pekerjaan maupun yang bersifat pribadi.

b. Capacity, untuk melihat nasabah dalam kemampuannya dalam bidang bisnis yang dihubungkan dengan pendidikannya, kemampuan bisnis juga diukur dengan kemampuannya dalam memahami tentang ketentuan-ketentuan pemerintah. Begitu pula dengan kemampuannya dalam menjalankan usahanya selama ini. Pada akhirnya akan terlihat "kemampuannya" dalam mengembalikan kredit yang telah disalurkan.

c. Capital, untuk melihat penggunaan modal efektif, dilihat laporan keuangan (neraca dan laporan laba rugi) dengan melakukan pengukuran seperti dari segi likuiditas,solvabilitas, rentabilitas, dan ukuran lainnya.

d. Collateral, merupakan jaminan yang diberikan calon nasabah baik yang bersifat fisik maupun non fisik. Jaminan hendaknya melebihi jumlah kredit yang diberikan. Jaminan juga harus diteliti keabsahannya, sehingga jika terjadi suatu masalah, maka jaminan yang dititipkan akan dapat dipergunakan secepat mungkin.

e. Condition, dalam menilai kredit hendaknya juga dinilai kondisi ekonomi dan politik sekarang dan dimasa yang akan datang sesuai sektor masing-masing, serta prospek usaha dari sektor yang ia jalankan. 
Sedangkan metode analisis 7P, antara lain sebagai berikut :

a. Personality, adalah menilai nasabah dari segi kepribadian atau tingkah lakunya sehari-hari maupun masa lalunya. Selain itu juga mencakup sikap, emosi, tingkah laku dan tindakan nasabah dalm menghadapi masalah.

b. Party, adalah mengklasifikasi nasabah kedalam golongan-golongan tertentu berdasarkan modal, loyalitas dan karakternya sehingga nasabah akan mendapatkan fasilitas yang berbeda pula.

c. Perpose, untuk mengetahui tujuan nasabah dalam mengambil kredit, termasuk jenis kredit yang diinginkan nasabah.

d. Prospect, adalah menilai usaha nasabah di masa yang akan datang menguntungkan atau tidak atau dengan kata lain mempunyai prospek atau tidak.

e. Payment, adalah merupakan ukuran bagaimana cara nasabah mengembalikan kredit yang diambil atau dari sumber mana saja dana untuk pengembalian kredit.

f. Profitability, untuk menganalisis bagaimana kemampuan nasabah dalam mencari laba. Profitability diukur dari periode apakah akan tetap sama atau akan semakin meningkat apalagi dengan tambahan kredit yang diperolehnya.

g. Protection, tujuannya adalah bagaimana menjaga agar usaha dan jaminan mendapatkan perlindungan. Perlindungan dapat berupa jaminan barang atau orang atau jaminan asuransi.

\section{Kredit Macet}

Sebuah kredit digolongkan dalam kategori kredit macet apabila didalam kemampuan membayarnya terdapat tunggakan pokok dan atau bunga yang telah melampaui 270 hari. Kemudian setiap pinjaman baru akan dipergunakan untuk menutup kerugian operasionalnya. Menurut Siamat (2005:174), kredit macet atau problem loan dapat diartikan: "Sebagai pinjaman yang mengalami kesulitan pelunasan akibat adanya faktor kesengajaan dan atau karena faktor ekstemal di luar kemampuan kendali debitur". Adanya kredit macet ini menimbulkan kerugian pada pihak debitur yang disebabkan tidak berputarnya modal yang dimilikinya, sehingga akan menyebabkan menurunnya pendapatan bank, selanjutnya memungkinkan terjadinya penurunan laba.

Kredit macet dapat disebabkan oleh berbagai faktor, baik faktor eksternal ataupun faktor internal. Menurut Tangkilisan (2003:56) adapun faktor internal penyebab timbulnya kredit macet yaitu dikarenakan adanya kebijakan perkreditan yang ekspansif, penyimpangan dalam pelaksanaan prosedur kredit, adanya itikad yang kurang baik dari pemilik, pengurus, atau pegawai bank, lemahnya sistem administrasi dan pengawasan kredit serta lemahnya sistem inforrnasi kredit macet. Sedangkan faktor eksternal penyebab timbulnya kredit macet adalah karena kegagalan dari usaha debitur, musibah terhadap debitur atau terhadap kegiatan usaha debitur, serta menurunya kegiatan ekonomi dan tingginya suku bunga kredit, dan pemanfaatan iklim persaingan perbankan yang tidak sehat oleh debitur.

Sumber-sumber penyebab kegagalan/kesulitan kredit atau penyebab kredit bermasalah pada bank menurut Rivai dan Viethzal (2006:15), dapat dikemukakan sebagai berikut:

a. Self Dealing, terjadi karena adanya interst tertentu dari pejabat pemberi kredit terhadap permohonan yang diajukan nasabah, berupa pemberian kredit yang tidak layak atas dasar yang kurang sehat kepada nasabahnya. Hat ini timbul karena adanya harapan berupa kompensasi pemberiansuatu imbalan dari nasabah

b. Anxiety for income, adalah pendapatan perkreditan merupakan sumber pendapatan utama sebagaian besar bank sehingga ambisi yang berlebihan untuk memperoleh laba bank rnelalui penerimaan bunga kredit sering menimbulkan pertimbangan yang tidak sehat dalam pemberian kredit yang pada akhirnya akan menjadi beban berat jika kredit tersebut macet bila dibandirigkan dengan besarnya pendapatan bunga yang hendak diraih dari pemberian kredit.

c. Compromise of Credit Principles, adalah pelanggaran prinsip-prinsip kredit oleh pimpinan bank yang menyetujui pemberian kredit yang mengandung resiko yang potensial. Tindakan kompromitisyang dilakukan pimpinan bank terhadap nasabahnya terutama disebabkan oleh 
keeratan hubungan antara pejabat bank dengan nasabahnya dan kuatnya persaingan dalam bisnis perbankan.

d. Incomplete Credit Information, adalah terbatasnya data atau informasi yang diperlukan untuk mendukung evaluasi permohonan kredit seperti data keuangan dan laporan usaha, tujuan penggunaan kredit, perencanaan, ataupun keterangan mengenai sumber pelunasan kembali kredit.

e. Failure to Obtain Liquidation Agreements, merupakan sikap ragu-ragu dalam menentukan tindakan terhadap suatu kewajiban yang telah diperjanjikan, Hal lain yang menyebabkan timbulnya masalah ini karena tidak lengkapnya atau terdapat cacat hukum dalam dokumen perkreditan sehingga posisi yuridis bank menjadi lemah.

f. Complacency, merupakan sikap memudahkan suatu masalah dalam proses kredit yang mengakibatkan terjadinya kegagalan atas pelunasan kredit yang diberikan.

g. Lack of Supervising, adalah kurangnya pengawasan yang efektif dan berkesinambungan setelah pamberian kredit, kondisi kredit akan berkembang menjadi kerugian karena nasabah tidak memenuhi kewajibannya dengan baik.

h. Technical Incompetence, tidak adanya kemampuan teknis dalam menganalisis permohonan kredit dari aspek keuangan maupun aspek lainnya akan berakibat kegagalan dalam operasi perkreditan suatu bank.

i. Poor Selection of Risk, adalah kurangnya risiko yang dipahami oleh pejabat kredit, seperti risiko sifat uasaha, risiko geografis, risiko politik, risiko ketidakpastian, risiko inflasi, dan risiko persaingan.

j. Overlending, adalah pemberian kredit yang besarnya melampaui batas kemampuan pelunasan kredit oleh nasabah.

Usaha untuk menyelesaikan kredit yang dikategorikan macet dapat ditempuh dengan usaha-usaha sebagai berikut :

a. Rescheduling ( penjadwalan ulang), adalah perubahan syarat kredit hanya menyangkut jadwal pembayaran kredit dan atau jangka waktu termasuk masa tenggang, dan besarnya perubahan angsuran kredit. Tentu tidak semua debitur diberikan kebijakan ini oleh bank, melainkan hanya diberikan kepada debitur yang menunjukkan itikad dan karakter yang jujur dan memiliki kemampuan untuk membayar atau melunasi kredit. Disamping itu usaha debitur yang tidak memerlukan dana atau likuiditas.

b. Reconditioning (persyaratan ulang), adalah perubahan sebagian atau seluruh persyaratan kredit yang tidak terbatas pada perubahan jadwal pembayaran, jangka waktu, tingkat suku bunga, penundaan pembayaran sebagian atau seluruh bunga dan persyaratan lainnya. Perubahan persyaratan kredit tersebut tidak menyangkut penambahan dana atau injeksi dan konversi sebagian atau seluruh kredit menjadi equity perusahaan.

c. Restructuring (penataan ulang), adalah perubahan syarat kredit yang menyangkut penambahan dana bank atau konversi atau seluruh atau sebagian tunggakan menjadi bunga pokok kredit baru, dan atau konversi seluruh atau sebagian dari kredit menjadi persyaratan bank atau mengambil partner uang lain untuk menambah penyertaan.

d. Liquidation (likuidasi), adalah penjualan barang-barang yang dijadikan jaminan dalam rangka pelunasan utang. Pelaksanaan liquidasi ini dilakukan memang benar-benar pada kredit yang dikategorikan sudah tidak dapat lagi dibantu untuk disehatkan kembali atau usaha nasabah yang tidak dapat dilakukan dengan penyerahan penjualan barang tersebut kepada nasabah yang bersangkutan. Sedangkan bagi BUMN, proses penjualan barang jaminan dan asset bank dapat diserahkan kepada BPPN untuk selanjutnya dilakukan eksekusi atau pelelangan.

\section{Kerangka Analisis}

Jumlah Kredit Macet Setiap Bulan
Perkembangan Kredit Macet Setiap Bulan

Gambar 1. Kerangka Analisis 
HASIL PENELITIAN DAN PEMBAHASAN

Perkembangan Kredit Macet Untuk Produk Kredit Mikro pada PT. Bank Mandiri (Persero) Tbk. Unit KCP MMU Argamakmur

Kredit Usaha Mikro (KUM), merupakan produk perbankan yang sedang dikembangkan, dan bertujuan untuk membantu pengembangkan dan memajukan usaha kecil. Dalam penyaluran KUM juga perlu diwaspadai, karena sering terjadinya kredit bermasalah atau kredit macet. Hal ini juga terjadi pada PT. Bank Mandiri (Persero) Tbk. Unit KCP MMU Argamakmur dalam menyalurkan KUM kepada masyarakat juga sering terjadi kredit kurang lancar, diragukan dan macet.

Berikut ini perkembangan kredit bermasalah pada PT. Bank Mandiri (Persero) Tbk. Unit KCP MMU Argamakmur:

a. Perkembangan kredit kurang lancar, adalah KUM yang tingkat pengembalian sudah melewati 91-120 hari dari batas waktu (jatuh tempo) yang telah disepakati.

Tabel 1. Data Perkembangan Kredit Kurang Lancar Tahun 2012-Agustus 2013 (Dalam Jutaan Rp)

\begin{tabular}{|c|c|c|c|}
\hline Tahun & Bulan & Jumlah Kredit & Kurang Lancar \\
\hline \multirow[t]{12}{*}{2012} & Januari & 11.915 & - \\
\hline & Februari & 12.478 & - \\
\hline & Maret & 12.889 & - \\
\hline & April & 13.222 & - \\
\hline & Mei & 13.434 & 79 \\
\hline & Juni & 13.716 & - \\
\hline & Juli & 14.201 & 20 \\
\hline & Agustus & 14.498 & - \\
\hline & September & 14.855 & - \\
\hline & Oktober & 15.149 & 8 \\
\hline & November & 15.808 & - \\
\hline & Desember & 16.591 & 12 \\
\hline \multirow[t]{8}{*}{2013} & Januari & 16.668 & 7 \\
\hline & Februari & 16.989 & - \\
\hline & Maret & 17.349 & 8 \\
\hline & April & 17.499 & 7 \\
\hline & Mei & 19.052 & - \\
\hline & Juni & 20.796 & 9 \\
\hline & Juli & 21.015 & 43 \\
\hline & Agustus & 21.030 & 107 \\
\hline
\end{tabular}

Sumber: PT. Bank Mandiri Argamakmur, 2013

Dari tabel 1 di atas menunjukkan bahwa dari sisi penyaluran KUM dari bulan Januari 2012-Agustus 2013 terus mengalami kenaikkan, tetapi dilihat dari angsuran kredit terjadi fluktuasi setiap bulan karena ada beberapa bulan baik dalam tahun 2012 maupun 2013 ada beberapa bulan tingkat pengembalian kredit kurang lancar.

Berikut grafik perkembangan KUM yang kurang lancar dari Januari 2012-Agustus 2013.

Gambar 2. Perkembangan Kredit Kurang Lancar Tahun 2012-Agustus 2013

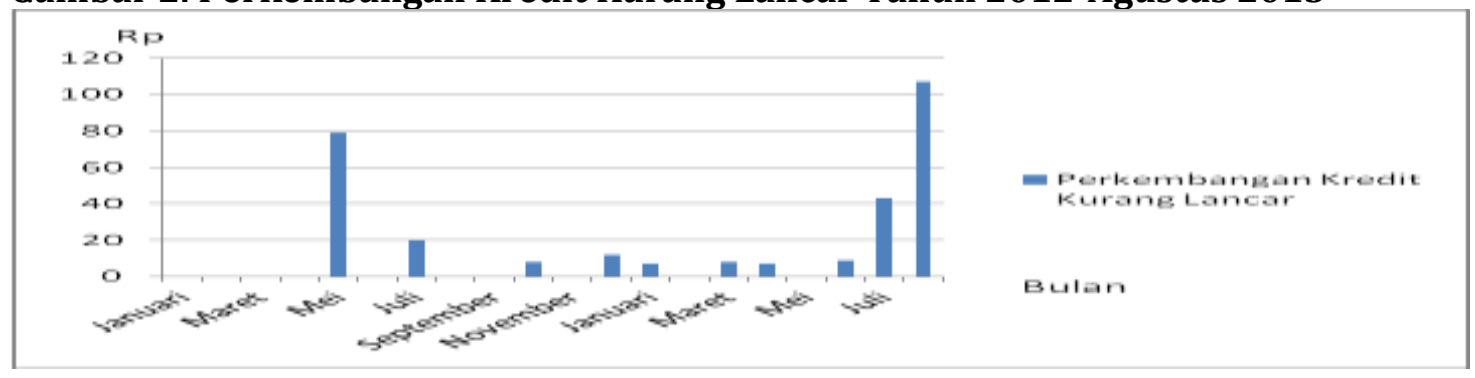

Sumber: PT. Bank Mandiri Argamakmur, 2013 
Dari gambar 2 di atas menunjukkan bahwa kredit kurang lancar mulai terjadi pada bulan Mei 2012, dan nilai tertinggi kredit kurang lancar terjadi pada bulan Agustus 2013 yaitu sebesar Rp 107.000.000. hasil pengamatan peneliti rata-rata penyebab terjadinya kredit kurang lancar karena usaha kecil yang dibiayai oleh KUM kurang dapat berkembang dengan baik sehingga nasabah sering terlambat melakukan angsuran. Sedangkan jangka waktu angsuran kredit kurang lancar yaitu 3 bulan sebelum menjadi kredit diragukan.

b. Perkembangan kredit diragukan, adalah KUM yang tingkat pengembalian sudah melewati

121-180 hari dari batas waktu (jatuh tempo) yang telah disepakati.

Tabel 2. Data Perkembangan Kredit Diragukan Tahun 2012-Agustus 2013 (Dalam Jutaan Rp)

\begin{tabular}{|c|c|c|c|}
\hline Tahun & Bulan & Jumlah Kredit & Diragukan \\
\hline \multirow[t]{12}{*}{2012} & Januari & 11.915 & - \\
\hline & Februari & 12.478 & - \\
\hline & Maret & 12.889 & - \\
\hline & April & 13.222 & - \\
\hline & Mei & 13.434 & - \\
\hline & Juni & 13.716 & 79 \\
\hline & Juli & 14.201 & - \\
\hline & Agustus & 14.498 & 99 \\
\hline & September & 14.855 & - \\
\hline & Oktober & 15.149 & - \\
\hline & November & 15.808 & 8 \\
\hline & Desember & 16.591 & - \\
\hline \multirow[t]{8}{*}{2013} & Januari & 16.668 & 12 \\
\hline & Februari & 16.989 & 7 \\
\hline & Maret & 17.349 & - \\
\hline & April & 17.499 & - \\
\hline & Mei & 19.052 & 7 \\
\hline & Juni & 20.796 & - \\
\hline & Juli & 21.015 & - \\
\hline & Agustus & 21.030 & 33 \\
\hline
\end{tabular}

Sumber: PT. Bank Mandiri Argamakmur, 2013

Dari tabel 2 di atas menunjukkan kredit yang diragukan berawal dari kredit kurang lancar yang terus berkembang sehingga akhirnya diragukan tingkat pengembaliannya, seperti halnya kredit yang diragukan pada bulan Mei 2012 sebesar Rp 79.000 .000 sampai bulan Juni 2012 belum dapat diangsur sehingga jumlah tersebut diragukan pengembaliannya, begitu juga pada kredit kurang lancar bertambah pada bulan Juli sebesar Rp 20.000.000 sehingga kredit diragukan pada bulan Agustus menjadi Rp 99.000.000.

Berikut grafik perkembangan KUM yang diragukan dari Januari 2012-Agustus 2013.

\section{Gambar 3. Perkembangan Kredit Diragukan Januari 2012-Agustus 2013}

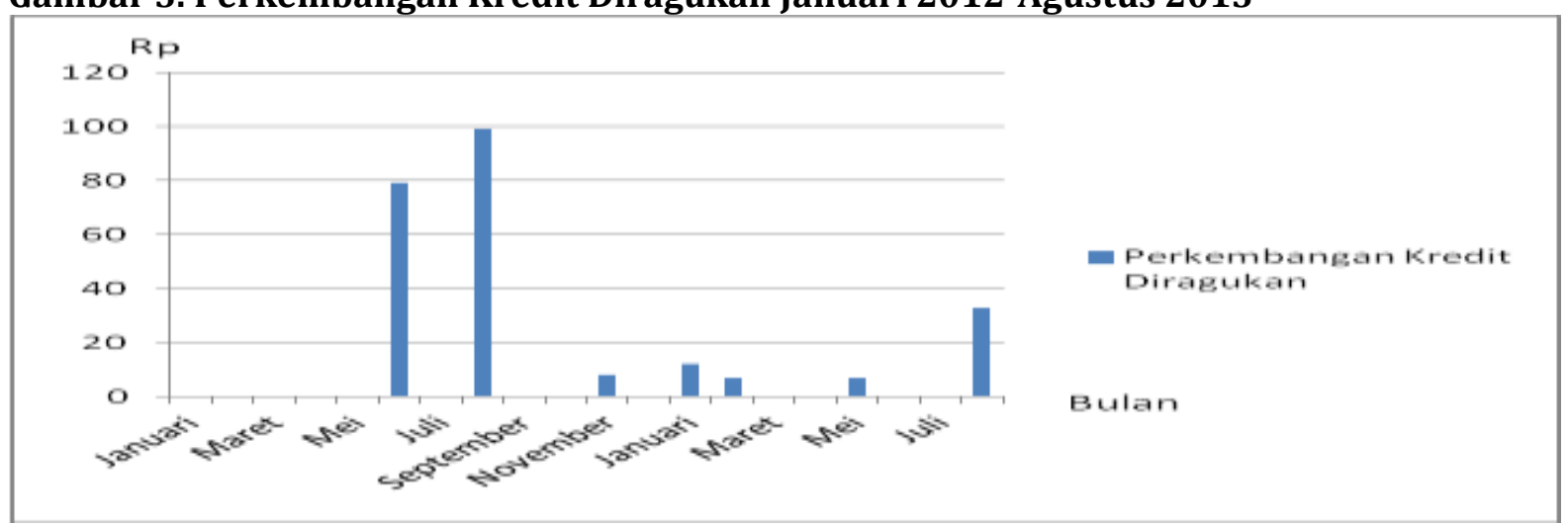

Sumber: PT. Bank Mandiri Argamakmur, 2013 
Dari gambar 3 di atas menunjukkan bahwa perkembangan kredit yang diragukan tingkat pengembaliannya terjadi penurunan walaupun pada bulan Agustus 2013 kembali naik menjadi Rp 33.000.000, hal ini menunjukkan bahwa walaupun tingkat pengembalian kedit tersebut diragukan tetapi nasabah kredit usaha mikro masih tetap berupaya untuk melakukan pembayaran atau angsuran.

c. Perkembangan kredit macet, adalah kredit usaha mikro yang tingkat pengembalian sudah melewati 181 hari dari batas waktu (jatuh tempo) yang telah disepakati.

Tabel 3. Data Perkembangan Kredit Macet Tahun 2012-Agustus 2013 (Dalam Jutaan Rp)

\begin{tabular}{|c|c|c|c|}
\hline Tahun & Bulan & Jumlah Kredit & Macet \\
\hline \multirow[t]{12}{*}{2012} & Januari & 11.915 & - \\
\hline & Februari & 12.478 & - \\
\hline & Maret & 12.889 & - \\
\hline & April & 13.222 & - \\
\hline & Mei & 13.434 & - \\
\hline & Juni & 13.716 & 79 \\
\hline & Juli & 14.201 & 79 \\
\hline & Agustus & 14.498 & 99 \\
\hline & September & 14.855 & 99 \\
\hline & Oktober & 15.149 & 99 \\
\hline & November & 15.808 & 107 \\
\hline & Desember & 16.591 & 9 \\
\hline \multirow[t]{8}{*}{2013} & Januari & 16.668 & 111 \\
\hline & Februari & 16.989 & 117 \\
\hline & Maret & 17.349 & 111 \\
\hline & April & 17.499 & 111 \\
\hline & Mei & 19.052 & 19 \\
\hline & Juni & 20.796 & 19 \\
\hline & Juli & 21.015 & 19 \\
\hline & Agustus & 21.030 & 52 \\
\hline
\end{tabular}

Sumber: PT. Bank Mandiri Argamakmur, 2013

Dari tabel 3 di atas menunjukkan kredit yang diragukan berawal dari kredit diragukan yang terus berkembang sehingga akhirnya masuk dalam kategori macet tingkat pengembaliannya. Dalam mengatasi kredit macet pihak Bank Mandiri terus melakukan pendekatan dengan nasabah hal ini ditunjukkan pada bulan Desember 2012 kredit macet turun menjadi Rp 9.000.000, walaupin pada bulan selanjutnya meningkat kembali tetapi bulan Juni 2013 kembali turun menjadi Rp 19.000.000. Hal ini menunjukkan bahwa walaupun sudah dikategorikan macet tetap dilakukan upaya pelunasan.

Berikut grafik perkembangan kredit usaha mikro yang masuk dalam ketegori macet dari Januari 2012-Agustus 2013.

\section{Gambar 4. Perkembangan Kredit Macet Januari 2012-Agustus 2013}

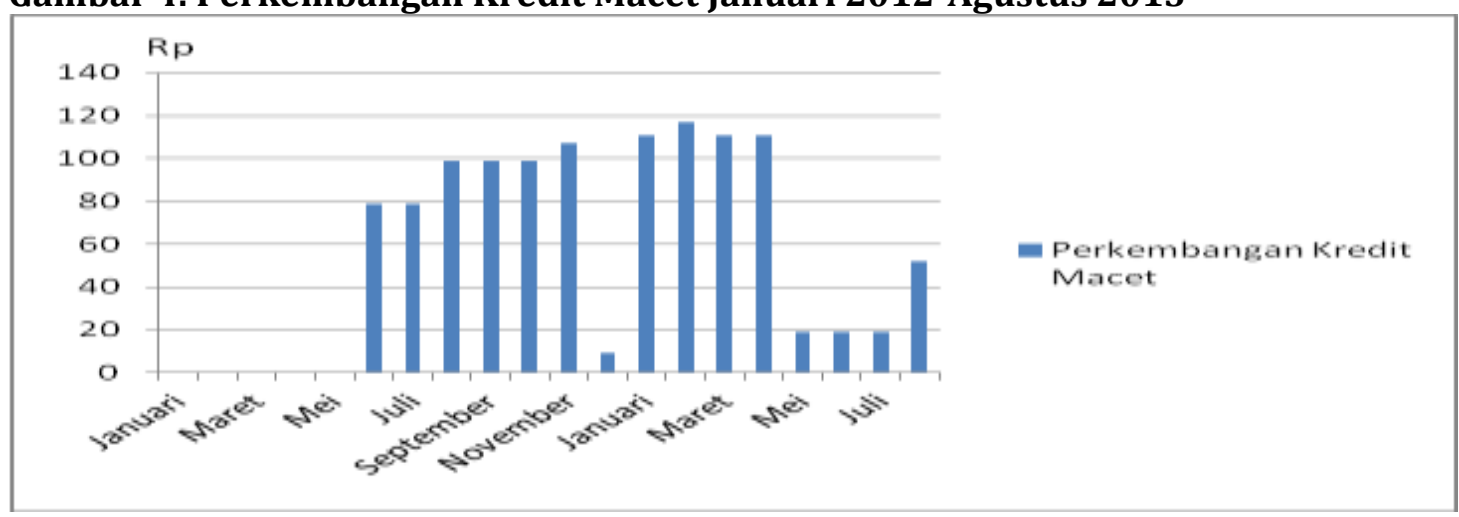

Sumber: PT. Bank Mandiri Argamakmur, 2013 
Dari gambar 4 di atas menunjukkan bahwa perkembangan kredit macet berawal dari kredit terus meningkat tetapi terjadi penurunan secara signifikan pada bulan Desember 2012 menjadi Rp 9.000.000, dan kembali meningkat menjadi Rp 117.000.000, dan bulan Mei 2013 kembali turun hingga bulan Agustus kembali naik menjadi Rp 52.000.000.

Untuk mengetahui kredit macet masih dalam posisi baik atau tidak maka akan dilakukan perhitungan Non Performing Loan (NPL) sebagai berikut:

NPL $\quad=\frac{\text { Total Kredit Bermasalah }}{\text { Total Kredit }} \times 100 \%$

Tabel 4. Perhitungan Non Performing Loan (NPL)

\begin{tabular}{|c|c|c|c|c|c|}
\hline Tahun & Bulan & Bade & Macet & NPL (\%) & Ket \\
\hline \multirow[t]{12}{*}{2012} & Januari & 11.915 & - & 0 & Baik \\
\hline & Februari & 12.478 & - & 0 & Baik \\
\hline & Maret & 12.889 & - & 0 & Baik \\
\hline & April & 13.222 & - & 0 & Baik \\
\hline & Mei & 13.434 & - & 0 & Baik \\
\hline & Juni & 13.716 & 79 & 0,58 & Baik \\
\hline & Juli & 14.201 & 79 & 0,56 & Baik \\
\hline & Agustus & 14.498 & 99 & 0,68 & Baik \\
\hline & September & 14.855 & 99 & 0,67 & Baik \\
\hline & Oktober & 15.149 & 99 & 0,65 & Baik \\
\hline & November & 15.808 & 107 & 0,68 & Baik \\
\hline & Desember & 16.591 & 9 & 0,05 & Baik \\
\hline \multirow[t]{8}{*}{2013} & Januari & 16.668 & 111 & 0,67 & Baik \\
\hline & Februari & 16.989 & 117 & 0,69 & Baik \\
\hline & Maret & 17.349 & 111 & 0,64 & Baik \\
\hline & April & 17.499 & 111 & 0,63 & Baik \\
\hline & Mei & 19.052 & 19 & 0,10 & Baik \\
\hline & Juni & 20.796 & 19 & 0,09 & Baik \\
\hline & Juli & 21.015 & 19 & 0,09 & Baik \\
\hline & Agustus & 21.030 & 52 & 0,25 & Baik \\
\hline
\end{tabular}

Sumber: Hasil Penelitian, 2013

Kreteria:

$0 \% \quad-5 \% \quad=$ Baik (Sehat)

Di atas $5 \%=$ Tidak Baik (Tidak Sehat)

Dari tabel 4 di atas menunjukkan bahwa kredit macet pada PT. Bank Mandiri (Persero) Tbk. Unit KCP MMU Argamakmur khususnya untuk Kredit Usaha Mikro dari bulan Januari 2012Agustus 2013 masih dalam kriteria baik (sehat), karena persentase NPL berada antara 0\% - 5\% dengan kriteria baik (sehat).

\section{Pembahasan}

Dari hasil penelitian di atas bahwa jumlah kredit kurang lancar, kredit diragukan dan kredit akhir periode seperti pada tabel 4 .

Tabel 4. Jumlah Kredit Bermasalah Akhir Periode

\begin{tabular}{|l|c|c|}
\hline \multicolumn{1}{|c|}{ Keterangan } & Desember 2012 & Agustus 2013 \\
\hline Kredit Kurang Lancar & 12 & 107 \\
\hline Kredit Diragukan & - & 33 \\
\hline Kredit Macet & 9 & 52 \\
\hline
\end{tabular}

Sumber: Hasil Penelitian, 2013

Seperti yang telah dijelaskan sebelumnya bahwa kredit macet berawal dari yang bermasalah, mulai dari kredit kurang lancar yang berkembang menjadi kredit diragukan dan 
pada akhirnya menjadi macet. Kredit macet disebabkan karena nasabah kredit usaha mikro memiliki usaha yang tidak dapat berkembang dengan baik. terjadinya kredit bermasalah harus dapat diatasi baik oleh pihak Bank Mandiri maupun dari pihak nasabah. Pihak Bank Mandiri terus berupaya melakukan berbagai pendekatan kepada nasabah dan berusaha memberi berbagai solusi kepada nasabah agar kredit bermasalah tersebut mulai dari kredit kurang lancar tidak berkembang menjadi kredit diragukan dan kredit macet.

Upaya mengatasi kredit bermasalah harus dimulai dari penyeleksian calon nasabah. PT. Bank Mandiri (Persero) Tbk. Unit KCP MMU Argamakmur dalam mengatasi agar tidak terjadi kredit bermasalah hingga terjadi kredit macet, melakukan hal-hal sebagai berikut:

a. Initiation.

Dalam proses ini debitur melakukan pengisian formulir permohonan kredit usaha mikro, beserta dengan menyerahkan dokumen-dokumen pendukung lainnya seperti: copy Kartu Tanda Penduduk suami istri yang masih berlaku, copy Kartu Keluarga, copy Surat Nikah/Surat Keterangan Belum Menikah/Janda/Duda, Surat Keterangan Usaha/Domisili Usaha/ Surat Ijin Usaha (SIUP) dan Tanda Daftar Perusahaan (TDP) dari Instansi yang berwenang, copy NPWP (untuk limit tertentu yang mensyaratkan adanya NPWP atau menurut ketentuan perundangan yang berlaku), copy Agunan SHM/BPKB beserta SPPT PBB/ STNK, rekening listrik/rekening telepon (kalau ada), pas photo ukuran 4 x 6 berwarna.

Setelah dokumen-dokumen pundukungnya lengkap kemudian Mikro Kredit Sales akan melakukan pengecekan dan meneliti kaitannya untuk memastikan bahwa dokumendokumen yang diajukan masih berlaku lengkap, sah dan berkekuatan hukum.

b. Verification.

Keputusan kredit sangat dipengaruhi oleh keakuratan data dan informasi. Bank harus mengecek keakuratan data dan informasi yang akan dilaporkannya dalam bentuk Laporan Kunjungan Nasabah (LKN). LKN tersebut melalui verifikasi data seperti:

1. Verifikasi data debitur, penghasilan dan agunan yang disampaikan calon debitur. Data yang diinformasikan oleh calon debitur harus diverifikasi dengan metode verifikasi sebagai berikut:

a) Verifikasi Dokumen, adalah pengecekan kelengkapan dokumen yang diserahkan calon debitur dan mencocokkan kesesuaian nama dan alamat pada KTP, Kartu Keluarga, Akta Nikah dan rekening pribadi, termasuk kesesuaian dengan Surat Ijin Usaha/Praktek (untuk wiraswasta/ professional).

b) Verifikasi penghasilan, adalah penelitian/pengecekan atas informasi yang diberikan calon debitur berkaitan dengan penghasilan calon debitur dan pasangannya (bila joint income) dengan cara antara lain:

1) Interview baik melalui kunjungan langsung maupun telepon kepada calon debitur dan ke kantor/tempat usaha calon debitur.

2) Pengecekan silang dengan data yang disampaikan calon debitur seperti slip gaji, rekening giro/tabungan atau laporan keuangan.

c) Verifikasi agunan, adalah penelitian/pengecekan atas bukti dokumen agunan debitur pada kantor/instansi yang mengeluarkannya misalnya sertifikat tanah pada Kantor Pertanahan, BPKB kendaraan bekas pada Polda setempat.

d) Investigasi, adalah penelitian/pengecekan atas informasi yang diberikan calon debitur berkaitan dengan alamat rumah tinggal dan alamat kantor baik dengan cara kunjungan langsung (on the spot) maupun melalui telepon. Pengecekan tersebut untuk mengetahui status kepemilikan rumah tinggal, lama menempati, jumlah tanggungan, status kantor, jumlah karyawan, skala usaha, papan nama, gedung dan aktivitas kantor/usaha.

2. Verifikasi fasilitas kredit yang telah dimiliki calon debitur. Fasilitas kredit yang telah dimiliki calon debitur dapat diketahui melalui Sistem Informasi Debitur Bank Indonesia, yaitu salah satu cara untuk mengenal debitur dengan lebih baik adalah melalui checking. Credit checking merupakan media verifikasi mengenai reputasi dan untuk memperoleh keyakinan atas kondisi usaha calon debitur. Oleh karenanya setiap pemberian kredit harus dilakukan credit checking secara berkala. Credit checking dilakukan melalui: 
a) Bank Checking, dilakukan melalui:

1. Bank to Bank Information Internal Bank Mandiri, yaitu melakukan klarifikasi pada unit-unit kerja internal Bank Mandiri untuk mengetahui informasi rekening, fasilitas kredit yang diperoleh sebelumnya dan performance kredit sebelumnya (bila ada).

2. Informasi Debitur Individual (IDI) kepada Bank Indonesia, adalah informasi mengenai apakah orang atau suatu perusahaan telah mendapat fasilitas kredit atau menjadi debitur di salah satu bank dan kolektibilitas kreditnya. Bank dapat secara langsung menghubungi Bank Indonesia (direct access) untuk meminta Informasi Debitur Individual melalui Credit Operation.

b) Trade Checking, dilakukan kepada sejumlah supplier, pelanggan, distributor, asosiasi terkait usaha debitur, dan pihak lain yang dipandang perlu oleh Bank. Di samping itu, checking dapat dilakukan langusng ke lapangan/market checking (misal ke pasar) untuk mengetahui brand image dari produk debitur. Pelaksanaan trade checking dilakukan secara taktis dan strategis, dimana kepada debitur yang telah lama berhubungan dengan Bank Mandiri dan atau debitur yang telah mempunyai nama besar agar dilakukan lebih hati-hati dan seksama terutama hal-hal yang menyangkut reputasi.

c) Referensi, adalah informasi yang diperoleh secara langsung dari debitur Bank Mandiri atau dari Manajemen Bank yang menunjukkan bahwa calon debitur layak untuk diberikan kredit.

d) Analysis/scoring, adalah setelah proses initiation dan verification telah dilakukan, maka proses selanjutnya adalah analysis/scoring yang dalam hal ini dilakukan oleh MKA dengan melakukan entry data infomasi dan dokumen dari berkas pemohonan kredit debitur kedalam sistem LOS mikro, yang nantinya hasil scoring tersebut akan memberikan usulan kepada KCM berupa analisis dan usulan yaitu tidak direkomendasikan atau direkomendasikan. Apabila usulan berupa direkomendasikan maka MKS kemudian membuat Nota Analisa Kredit (NAK) yang merupakan media untuk mengusulkan dan menganalisa permohonan kredit (baru, tambahan, perpanjangan) dari debitur/calon debitur untuk mendapatkan persetujuan dari pemegang kewenangan sesuai limit kewenangannya. Sedangkan bila usulan berupa tidak direkomendasikan maka MKS langsung membuat Surat Penolakan Kredit (SPK) atas permohonan kredit yang diajukan calon debitur. Hal ini dilakukan untuk menjaga adanya persepsi dan pandangan calon debitur yang ketika permohonan kreditnya tidak disetujui mendapatkan jawaban yang jelas .

e) Credit approval, merupakan approved atau pemutusan kredit yang dilakukan oleh KCM atas usulan dan rekomendasikan MKA melalui entry data dalam LOS web mikro. Pemutusan kredit disetujui atau ditolaknya atas usulan permohonan kredit debitur, sebaiknya selalu memperhatikan dan mempertimbangkan aspek $5 \mathrm{C}$ dan $7 \mathrm{P}$ untuk mendapatkan kualitas kredit yang baik. Setelah dilakukan pemutusan kredit maka MKS mempersiapkan SPK jika kredit tersebut ditolak, sebaliknya MKS akan membuat Surat Penawaran Pengajuan Kredit (SPPK) kepada calon debitur. Apabila debitur setuju atas SPPK tersebut, maka MKS mempersiapkan dokumen pengikatan agunan dan perjanjian kedit. Calon debitur juga diwajibkan untuk menyerahkan dokumen asli dan membayar biaya-baiya yang timbul atas pencairan kredit tersebut, diantaranya adalah biaya administrasi, provisi serta asuransi dan pengikatan notaris.

f) Legal documentations, setelah semua kewajiban calon debitur untuk menyerahkan dokumen asli dan membayar sejumlah biaya-biaya yang timbul dari pada pencairan kredit tersebut dilengkapi dan setujui, kemudian MKA melakukan compliance review dokumen untuk mengecek kelengkapan data dan dokumen yang diserahkan oleh calon debitur, setelah data dan dokumen lengkap dipenuhi oleh calon debitur maka dilakukan akad penandatanganan kredit oleh debitur yang akan disampaikan oleh KCM. 
g) Disbursement, proses selanjutnya adalah pencairan kredit, setelah KCM meneliti daan memastikan bahwa debitur telah menyerahkan dokumen asli dan membayar sejumlah biaya yang timbul serta debitur telah menyetujuinya dengan melakukan penandatangan perjanjian kredit, maka KCM akan memberikan otorisasi kepada MKS untuk membuat nota pencairan kredit ke rekening tabungan debitur.

Perkembangan kredit bermasalah khususnya kredit macet pada PT. Bank Mandiri (Persero) Tbk. Unit KCP MMU Argamakmur dapat dari bulan Januari 2012 sampai Agustus 2013, masih dapat diupayakan atau diatasi oleh pihak bank, hal ini ditunjukkan adanya kredit macet pada bulan Juni 2012 sebesar Rp 79.000.000 hingga naik sebesar Rp 107.000.000 masih dapat diupayakan angsurannya sehingga pada bulan Desember 2012 kredit macet tersisa Rp 9.000.000. Begitu yang terjadi pada bulan Januari 2013 kredit macet naik kembali sebesar Rp 111.000.000, tetapi pada bulan Agustus 2013 masih dapat diupayakan pelunasan angsuran sehingga kredit macet tersisa sebesar Rp 52.000.000.

Selain itu dari hasil analisis dengan menggunakan rasio NPL kredit macet pada PT. Bank Mandiri (Persero) Tbk. Unit KCP MMU Argamakmur khususnya Kredit Usaha Mikro masih berada pada kriteria baik (sehat) karena persentasi NPL berada dibawah 5\%. Hal ini menunjukkan bahwa besaran kredit macet yang terjadi masih dapat ditolelir karena belum mengganggu kredibilitas bank.

Terjadinya kredit macet pada PT. Bank Mandiri (Persero) Tbk. Unit KCP MMU Argamakmur disebabkan dua faktor, baik dari pihak bank maupun dari pihak nasabah. Kesalahan dalam menganalisa kemampuan calon nasabah merupakan faktor yang dapat menyebabkan kredit macet. Begitu juga usaha yang dibiayai dengan kredit mikro tidak dikelola dengan baik sehingga usaha tidak dapat berkembang dan angsuran kredit tidak dapat dilakukan. Hal ini sejalan dengan pendapat yang dijelasakan oleh Tangkilisan (2003:56), kredit macet dapat disebabkan oleh berbagai faktor, baik faktor eksternal ataupun faktor internal. Menurut adapun faktor internal penyebab timbulnya kredit macet yaitu dikarenakan adanya kebijakan perkreditan yang ekspansif, penyimpangan dalam pelaksanaan prosedur kredit, adanya itikad yang kurang baik dari pemilik, pengurus, atau pegawai bank, lemahnya sistem administrasi dan pengawasan kredit serta lemahnya sistem inforrnasi kredit macet. Sedangkan faktor eksternal penyebab timbulnya kredit macet adalah karena kegagalan dari usaha debitur, musibah terhadap debitur atau terhadap kegiatan usaha debitur, serta menurunnya kegiatan ekonomi dan tingginya suku bunga kredit, dan pemanfaatan iklim persaingan perbankan yang tidak sehat oleh debitur.

\section{Kesimpulan}

1. Kredit macet dimulai terjadinya kredit kurang lancar, sehingga menjadi kredit diragukan yang akhirnya menjadi kredit macet.

2. Perkembangan kredit macet pada tahun 2012, mulai terjadi pada bulan Juni 2012 sebesar Rp 79.000.000 hingga nilai tertinggi kredit macet terjadi pada bulan November 2012 sebesar Rp 107.000.000, tetapi hal tersebut masih dapat dilakukan upaya pelunasan angsuran oleh nasabah sehingga pada bulan Desember 2012 tersisa kredit macet sebesar Rp 9.000.000.

3. Pada tahun 2013 pada bulan Januari kembali naik menjadi Rp 111.000.000, tetapi upaya penagihan dan pendekatan pada nasabah tetap dilakukan sehingga bulan Mei 2013 turun menjadi sebesar Rp 19.000.000 walaupan pada bulan Agustus 2013 naik kembali menjadi Rp 52.000 .000 .

4. Nilai kredit macet masih dalam kriteria baik (sehat) karena nilai NPL masih berada antara $0 \%-5 \%$.

\section{Saran}

Dari hasil penelitian perkembangan kredit macet terus berfluktuasi, untuk itu peneliti menyarankan agar pihak PT. Bank Mandiri (Persero) Tbk. Unit KCP MMU Argamakmur dapat melakukan analisis yang lebih teliti tentang calon nasabah dan usahanya. Selain itu pendekatan 
dengan nasabah dengan memberi pengarahan dan masukan tentang usaha yang dikelola agar usaha dapat berkembang dengan baik karena akan berpengaruh terhadap kelancaran dalam membayar angsuran, begitu juga kredit macet masih dapat diupayakan pelunasannya.

\section{DAFTAR PUSTAKA}

Edaran Bank Indonesia Nomor: 3/30/DPNP Tangal 14 Desember 2001 Tentang Laporan Keuangan Publikasi Triwulan dan Bulanan Bank umum Serta Laporab Tertentu yang Disampaikan Kepada Bank Indonesia.

Handoko, T. Hani. 2008. Manajemen. Yogyakarta. BPFE.

Hasibuan, S.P Malayu. 2008. Dasar-Dasar Perbankan. Bumi Aksara. Jakarta.

Hasibuan, S.P Malayu. 2008. Manajemen Dasar, Pengertian dan Masalah. PT. Toko Gunung Agung. Jakarta.

Bank Rakyat Indonesia. 2011. Penelitian Terhadap Nasabah UMKM di Jepara yang Mengambil Kredit pada BRI Cabang Jepara.

Kasmir. 2008. Bank dan Lembaga Keuangan Lainnya. Jakarta. PT. RajawaliGrafindo Persada.

Muljono, Teguh Pudjo. 2001. Manajemen Perkreditan Bagi Bank Komersil. Yogyakarta. BPFE.

Novitasari, Rizki M. 2010. Faktor-Faktor Yang Mempengaruhi Resiko Kredit Macet Pada Koperasi Jasa Keuangan Syariah (KJKS) Amanah Ummah Surabaya. Jawa Timur. Skripsi Fisip UPN Veteran

Rivai, Veitzal, Andria Permata Veithzal dan Ferry N. Idroes. 2006. Bank And Financial Institution Management Conventional dan Sharia System. Jakarta. PT.Raja Grafindo Persada.

Siamat, Dahlan. 2005. Manajemen Lembaga Keuangan. Jakarta. FE UI.

Sugiyono. 2010. Metode Penelitian Kuantitatif, Kualitatif dan R\&D. Bandung. Alfabeta.

Sugiyono. 2010. Metode Penelitian Bisnis. Bandung. Alfabeta.

Suhardjono dan Kuncoro. 2002. Manajemen Perkreditan. Yogjakarta. UPP AMP UKPN.

Sutojo, Siswanto. 2000. Analisa Kredit Bank Umum. Jakarta. PT. Pustaka Binaman Pressindo.

Suyatno, Thomas, dkk. 2007. Dasar-Dasar Perkreditan. Jakarta. PT. Gramedia Pustaka Utama. Taswan. 2003. Manajemen Perbankan. Yogyakarta. UPP STIM YKPN.

Tangkilisan, Hessel Nogi S, 2003. Manajemen Keuangan Bagi Analisis Kredit Perbankan. Jakarta. $\mathrm{CO}$

Terry, George R dan Rue, Leslie W. 2005. Dasar-Dasar Manajemen. Jakarta. Bumi Aksara.

Undang-Undang Perbankan Nomor 10 Tahun 1998. Tentang Perbankan. Jakarta. Sinar Grafika. 